\title{
Integrating biological indicators in a Soil Monitoring Network (SMN) to improve soil quality diagnosis - a case study in Southern Belgium (Wallonia)
}

\author{
Inken Krüger ${ }^{(1)}$, Caroline Chartin ${ }^{(2)}$, Bas van Wesemael ${ }^{(2)}$, Sandrine Malchair ${ }^{(1)}$, \\ Monique Carnol (1) \\ (1) Université de Liège. Laboratoire d'Écologie végétale et microbienne. Botanique B22. Quartier Vallée, 1. Chemin de la \\ Vallée, 4.BE-4000 Liège (Belgique).E-mail : inken.kruger@ulg.ac.be \\ (2) Université Catholique de Louvain. Georges Lemaître Centre for Earth and Climate Research-Earth and Life Institute. \\ Place Louis Pasteur, 3 bte L4.03.08. BE-1348 Louvain-la-Neuve (Belgique).
}

Received on January 13, 2016; accepted on October 18, 2016.

This article is distributed under the terms and conditions of the CC-BY License (http://creativecommons.org/licenses/by/4.0)

Description of the subject. Soil organisms and their activities are essential for soil ecosystem functioning and they can thus be used as pertinent indicators of soil quality. Recent efforts have been undertaken to include biological indicators of soil quality into regional/national monitoring networks.

Objectives. The aim of this study was to provide a first dataset of six biological indicators and two eco-physiological quotients for two landscape units in Wallonia. These spatial units are characterized by homogeneous climate conditions, soil type, land-use and management (here, grasslands in the Ardennes, and croplands in the Loam Region).

Method. Respiration potential, microbial biomass carbon and nitrogen, net nitrogen mineralization, metabolic potential of soil bacteria and earthworm abundance were measured at a total of 60 sites in two different landscape units (LSU). Variability within each LSU was studied. Data was synthesized through calculation of a comprehensive score and presentation as radar plots.

Results. All selected biological indicators were significantly higher under grassland than under cropland soils, highlighting the biological indicators' power of discrimination between main land use types. Variability within LSU depended on the biological indicator and was generally higher in grassland than in cropland soils. Each site could unambiguously be assigned to its landscape unit based on its calculated comprehensive score. Radar plots allowed an assessment of the distribution of values within a landscape unit at a glance.

Conclusions. The pilot-study defined the first baseline values for agricultural soils in Wallonia and laid the foundation for a monitoring network of biological soil quality.

Keywords. Biological indicators, networks, monitoring, soil biology, Belgium.

L'intégration d'indicateurs biologiques dans un réseau de surveillance des sols afin d'améliorer le diagnostic de la qualité du sol - une étude de cas dans le sud de la Belgique (Wallonie)

Description du sujet. Les organismes du sol ainsi que leurs activités sont essentiels pour le fonctionnement de l'écosystème du sol et peuvent être employés comme indicateurs pertinents de la qualité du sol. Des efforts ont récemment été menés pour intégrer les indicateurs biologiques de la qualité du sol dans les réseaux régionaux/nationaux de surveillance.

Objectifs. Le but de cette étude était d'acquérir un premier set de données pour six indicateurs biologiques et deux quotients éco-physiologiques pour deux unités paysagères en Wallonie. Ces unités spatiales sont caractérisées par des conditions de climat, de type de sol et d'utilisation de terrain similaires (prairies en Ardenne et cultures en Région Limoneuse).

Méthode. La respiration potentielle, la biomasse microbienne (le carbone et l'azote microbien), la minéralisation nette de l'azote, le potentiel métabolique des bactéries du sol et l'abondance de vers de terre ont été mesurés pour un total de 60 sites répartis dans les deux unités paysagères. La variabilité des mesures dans les unités de paysage est calculée. Les données sont synthétisées via le calcul de scores compréhensifs et la présentation sous forme de plots radar.

Résultats. Tous les indicateurs biologiques sélectionnés présentent des valeurs significativement supérieures dans les sols de prairie par rapport à ceux de culture, soulignant le pouvoir discriminant des indicateurs biologiques pour les principales 
utilisations de sol. La variabilité dans les unités paysagères diffère selon l'indicateur biologique considéré et est généralement plus élevée pour les sols de prairie que ceux de culture. Chaque site peut sans équivoque être attribué à son unité de paysage sur base de son score compréhensif. Les plots radar illustrent la distribution des données.

Conclusions. L'étude pilote définit les premières gammes de valeurs pour les indicateurs biologiques dans les sols agricoles en Wallonie et présente une base solide pour un réseau de surveillance de la qualité biologique du sol.

Mots-clés. Indicateur biologique, réseau, surveillance, biologie du sol, Belgique.

\section{INTRODUCTION}

Soil quality has been defined as "the capacity of a specific kind of soil to function, within natural or managed ecosystem boundaries, to sustain plant and animal productivity, maintain or enhance water and air quality, and support human health and habitation" (Karlen et al., 1997). The awareness for the extent and impact of human activity on soils has grown since the 1990s and interest in soil quality has been increasing among scientists and policy makers (Arrouays et al., 2012). Soils are considered to be a non-renewable resource within human lifetime (Lal, 2009). For an early detection of soil degradation at landscape or regional scale and to counteract the decline of soil functions, Soil Monitoring Networks (SMN) are required (Arrouays et al., 2012).

A SMN is a set of sites or areas where changes in soil characteristics are documented through periodic assessment of an extended set of soil properties (Morvan et al., 2008). Most member states of the European Union (EU), including Belgium, have SMN with varying goals, duration and methods (Goidts \& van Wesemael, 2007; Rutgers et al., 2009; Arrouays et al., 2012). Soil characteristics and functions are measured with physical, chemical and biological indicators. Physical and chemical indicators, such as soil $\mathrm{pH}$, particle size distribution, element contents, and bulk density, have been recorded in monitoring networks for decades. Soil Organic Carbon (SOC) is widely accepted as the most important chemical indicator of soil quality. It is linked to provision of food, fiber and water (Koch et al., 2013). Furthermore, an increase in SOC stocks is considered to be a potential mechanism for climate change mitigation (Smith et al., 2008). However, at least a decade is required to detect changes in SOC stocks (Smith, 2004; Saby et al., 2008; Schrumpf et al., 2011).

Biological indicators have been defined as organisms or biological processes providing an early diagnosis of changes in the environment (Ramade, 2008; Malchair et al., 2010). In contrast to SOC, biological indicators of soil quality, such as basal respiration or microbial biomass, have been shown to react to changes within days or months (Bending et al., 2004; Bünemann et al., 2006; Dilly et al., 2011). Such indicators might therefore be more relevant for detecting changes of soil quality at an early stage. Recent efforts to introduce biological indicators into soil monitoring networks have been made at the regional, national and EU-wide scale (Bispo et al., 2009; Gardi et al., 2009). Despite European initiatives such as ENVASSO (Bispo et al., 2009) and ECOFINDERS (Stone et al., 2016a), current SMN and the stage of inclusion into a regular measurement network reflect national or regional choices of measured indicators, methodologies and site selection (Malchair et al., 2010). The Dutch biological SMN is considered as the most complete in Europe (Havlicek, 2012). Twenty-five soil parameters, including 12 biological indicators, are measured at 300 locations in a six-year cycle (Rutgers et al., 2009).

The inclusion of biological indicators of soil quality into a SMN requires several steps:

- definition of a goal,

- selection of suitable biological indicators,

- choice of study sites,

- definition of baseline values,

- the compilation of data into synthesized forms for decision makers.

Complex patterns of soil microbial properties across landscapes (Cavigelli et al., 2005) need to be considered when establishing a soil quality monitoring network. Variability, the change over space or time in the value of a given property (Ettema \& Wardle, 2002), impacts the magnitude of defined baseline values and the power to detect long-term trends. This variability restrains the possibility of extrapolating baseline values from published data. After the first three steps, a representative number of sites thus need to be sampled to define baseline values, essential for the interpretation of measurements (Nielsen \& Winding, 2002).

The concept "soil quality" comprises measures of several indicators, which need to be synthesized for comparison across sites and for assessment of changes in the environment. Different mathematical and graphical methods exist to transform the datasets into more easily understandable forms that can be used to answer specific questions (Andrews et al., 2003). Synthesis of biological indicators into standardized scores presents a flexible, simple and inclusive tool leading to a holistic overview of biological soil quality (Liebig et al., 2001). Such scores are obtained by the transformation of raw data to a common unitless scale, allowing mathematical operations to derive a single "comprehensive score" from several measurements. 
Scores are used in SMN of many countries, such as Spain, Poland and Italy (Bastida et al., 2008). Graphical approaches, like radar plots, sunray graphs or amoeba diagrams, are used to summarize soil data in other countries like the Czech Republic, France and The Netherlands (Hofman et al., 2003; Cluzeau et al., 2012; Rutgers et al., 2012), and present an appealing way to present the data in a visual form.

In Wallonia (Southern Belgium), changes in SOC content have been evaluated within 15 homogeneous "landscape units" (LSU), characterized by similar land use, soil type, climate and agricultural region (CARBOSOL network; Goidts et al., 2009a). While measurements of some biological indicators exist for individual sites (Buysse et al., 2013), no representative data on biological soil quality exist for agricultural sites in Wallonia. This pilot-study, CARBIOSOL, aims at the assessment of the current state of biological soil quality in Wallonia in a SMN. Six biological indicators as well as two eco-physiological quotients have been selected for the assessment, according to a literature review and the use of biological indicators in other countries (Malchair et al., 2010). The selected biological indicators are related to microbial activity (respiration potential, net nitrogen mineralization, microbial biomass $\left[\mathrm{C}_{\text {mic }}, \mathrm{N}_{\text {mic }}\right]$ ), microbial diversity (metabolic potential of soil bacteria) and soil fauna (earthworm abundance).

The general objective of this study was to provide first values for biological indicators of soil quality in
Wallonia at sites selected from two contrasting LSU within the CARBOSOL network. Specific aims were:

- to provide a first dataset for six biological indicators in two LSU and compare values to the literature,

- calculate the variability and required sample size within LSU,

- compare two methods to synthesize the datasets: comprehensive scores and radar plots.

\section{MATERIALS AND METHODS}

\subsection{Study site selections}

Two LSU (grasslands in the Ardennes and croplands in the Loam Region) with a total of 60 sites were selected from the CARBOSOL network (Figure 1). Shallow and stony soils are found in the Ardennes; the Loam Region encompasses fertile soils on niveoeolian silt loess (Goidts \& Westmael, 2007). The sites were previously sampled in 2005 for SOC stock assessment (Goidts \& Westmael, 2007) and marked with belowground electromagnetic markers (Ball Marker, 3M, Austin, Texas) to accurately locate the sites in future sampling campaigns.

\subsection{Soil sampling}

At each site, a composite soil sample $(0-10 \mathrm{~cm}$ soil depth) was taken in autumn 2013. It was mixed from

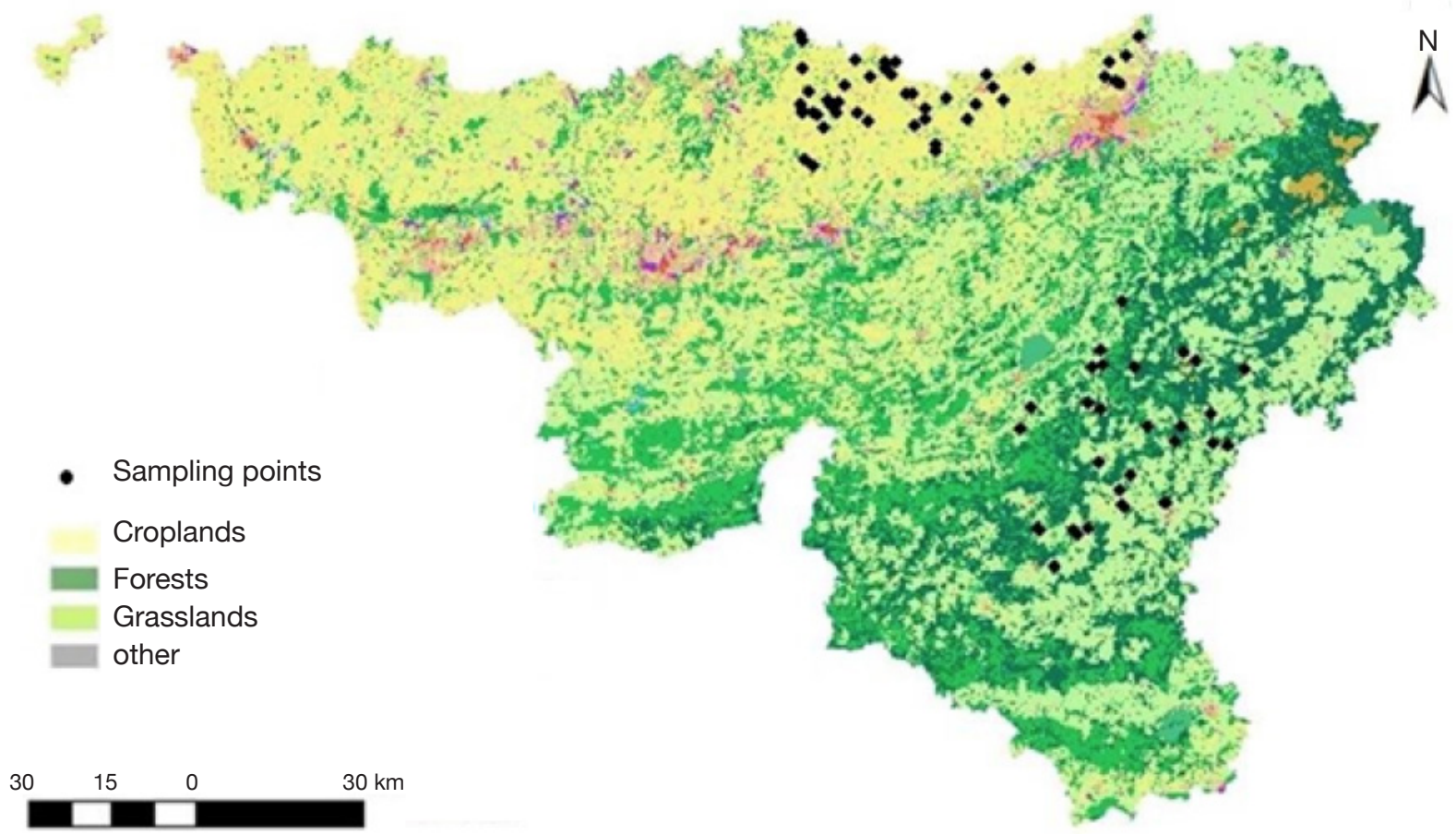

Figure 1. Map of sites sampled in autumn 2013 - Carte des sites échantillonnés en automne 2013. 
five individual samples taken between one and four meters from the center point with a manual auger following Goidts et al. (2009b). Fresh soil samples were sieved $\left(4 \mathrm{~mm}\right.$ ) and stored at $4{ }^{\circ} \mathrm{C}$ until analysis (Bloem et al., 2005). All measurements were made within a month of soil sampling. Soil moisture was determined after drying at $105^{\circ} \mathrm{C}$ for $3 \mathrm{~h}$ (Allen, 1989). Water holding capacity (WHC) of sieved soil was measured using a Haines-funnel system, where $50 \mathrm{ml}$ of water was added to $50 \mathrm{~g}$ of fresh soil for $30 \mathrm{~min}$. Excess water was collected and its volume measured (Jenkinson \& Powlson, 1976). Before biological analysis, soil samples were adjusted to $50-60 \%$ water holding capacity. The $\mathrm{pH}$ was measured in a suspension $(1: 1 ; \mathrm{m}: \mathrm{v})$ with distilled water with a $\mathrm{pH}$ meter (HI2550 HANNA instruments). Carbon and nitrogen were measured by element analysis (VarioMax CN dry combustion Analyzer, Elementar $\mathrm{GmbH}$, Germany).

\subsection{Earthworm abundance}

Earthworms were sampled in proximity of the marked sites, but outside of the sampling radius around each marker. Earthworms were extracted with two times 41 of mustard solution (3 and $6 \mathrm{~g}$ of mustard [Sinapis Albae Seminis Pulvis, Pharmaflore] $\cdot \mathrm{l}^{-1}$ respectively) (Gunn, 1992; Lawrence \& Bowers, 2002) on a $30 \times 60 \mathrm{~cm}$ surface marked with a wooden frame. All earthworms leaving the soil were collected and conserved in $70 \%$ ethanol. Earthworms were counted and their mass measured ( $\mathrm{g}$ biomass saturated with ethanol).

\subsection{Net nitrogen mineralization}

Net nitrogen mineralization was studied in a 29-day aerobic laboratory incubation at constant temperature $\left(25^{\circ} \mathrm{C}\right)$ in the dark (Hart et al., 1994). At the beginning and at the end of the incubation, inorganic nitrogen was extracted with $1 \mathrm{M} \mathrm{KCl}$ solution (1:5; w:v) (Allen, 1989) and analyzed colorimetrically using a continuous flow analyzer (AutoAnalyser3, BranLuebbe, Germany). The net nitrogen mineralization rate was calculated by dividing the net increase in inorganic nitrogen $\left(\mathrm{N}_{-} \mathrm{NH}_{4}^{+}\right.$ and $\mathrm{N}_{-} \mathrm{NO}_{3}^{-}$) during the incubation period by the number of incubation days.

\subsection{Microbial biomass}

Soil microbial biomass $\mathrm{C}$ and $\mathrm{N}$ were determined by the chloroform fumigation extraction method (Vance et al., 1987), followed by $0.5 \mathrm{M} \mathrm{K}_{2} \mathrm{SO}_{4}$ extraction of both fumigated and unfumigated soils. Fumigations were carried out for 3 days in a vacuum desiccator with alcohol-free chloroform. Fumigated and unfumigated extracts were filtered (Whatman Filter Papers 42, CAT No. 1442-150). In both extracts, dissolved organic carbon was measured with a Total Organic Carbon analyzer (Labtoc, Pollution and Process Monitoring limited, UK) and total $\mathrm{N}$ was measured colorimetrically using a continuous flow analyzer equipped with a UV digestion unit (Autoanalyser3, BranLuebbe, Germany). Soil microbial biomass $\mathrm{C}$ and $\mathrm{N}$ were calculated by dividing the difference of total extract between fumigated and unfumigated samples with a conversion factor of 0.45 for biomass C (Jenkinson et al., 2004) and 0.54 for biomass $\mathrm{N}$ (Joergensen, 1996).

\subsection{Respiration potential}

Respiration potential (Robertson et al., 1999) was measured as $\mathrm{CO}_{2}$ accumulation in the headspace $(250 \mathrm{ml})$ of an amber bottle (Supelco, USA) from $20 \mathrm{~g}$ fresh soil, at $15^{\circ} \mathrm{C}$ in the dark after an overnight preincubation. Gas samples (4 ml) were taken at 0,120 , 150 and 180 min with an air-tight syringe (Hamilton Model 1005) and analyzed with an infrared absorption gas analyzer (EGM-4, Ppsystem, UK). The respiration potential was estimated by linear regression of $\mathrm{CO}_{2}-\mathrm{C}$ against time $\left(\mu \mathrm{g} \cdot \mathrm{g}^{-1} \cdot \mathrm{h}^{-1}\right)$.

\subsection{Metabolic potential of soil bacteria}

BIOLOG ECOplates (BIOLOG ${ }^{\mathrm{TM}}$, California) with 32 wells each containing one of 31 different carbon substrates and one control well with water were used to assess metabolic potential of soil bacteria. Each well contained an oxidized tetrazolium dye, changing from colorless to purple when bacterial respiration oxidized the carbon source provided. One $g$ of fresh soil was extracted with $9 \mathrm{ml}$ of $0.1 \%$ sodium cholate and diluted to three dilutions $\left(10^{-2}, 10^{-3}, 10^{-4}\right)$ with $0.85 \% \mathrm{NaCl}$ to determine the number of CFU (colony forming units) on R2A agar. An aliquot of $100 \mu 1$ of the dilution corresponding to $1,000-2,000 \mathrm{CFU}$ was incubated for $72 \mathrm{~h}$ at $20^{\circ} \mathrm{C}$. Number of substrates used by bacteria were detected through visual observation of colored wells after incubation (Buysse et al., 2013).

\subsection{Eco-physiological quotients}

The metabolic quotient $\left(\mathrm{qCO}_{2}\right)$ represents the quantity of respired $\mathrm{CO}_{2}-\mathrm{C}$ per unit of soil microbial biomass and was calculated by dividing respiration potential by soil microbial biomass C (Anderson \& Domsch, 1990). The microbial quotient (qmic) represents the availability of soil $\mathrm{C}$ and was calculated by dividing microbial biomass C by total organic carbon (Anderson \& Domsch, 1990).

\subsection{Literature search}

The search engines Google Scholar and Scopus were used to retrieve scientific publications using the selected 
keywords "basal respiration", "earthworm abundance", "microbial biomass", "nitrogen mineralization" or "ecoplates biolog". Studies reporting values for at least one of the selected biological indicators as well as values of organic carbon, information on soil sampling and the applied methodologies were selected. Studies using different methodologies were used as long as the results were given in units that could be converted into the ones used in this study without additional information. Further, studies were selected based on sampling depth (overlap with a depth of $0-10 \mathrm{~cm}$ ) and site conditions similar to those studied (located in temperate zone, under cropland or grassland, no contamination with heavy metals or organic solvents).

\subsection{Data synthesis and analysis}

Comprehensive scores and radar plots were used to summarize and organize the individual values of different biological indicators. A comprehensive score of biological soil quality was calculated by converting measurements for each biological indicator into a score without units, which can then be unified into a single score (Karlen \& Stott, 1994; Rahmanipour et al., 2014). In this study, scores at each site were calculated by scaling individual biological indicators to values between 0 and 1 with

$$
\operatorname{SInd}_{i}=\frac{\operatorname{Ind}_{i}-\min (\operatorname{Ind})}{\max (\operatorname{Ind})-\min (\operatorname{Ind})}
$$

where SInd is the individual score of the biological indicator, Ind the unscaled value of the biological indicator and $\min / \max ($ Ind) the minimum or maximum unscaled value of the biological indicator of the whole dataset (van der Plas et al., 2016). Comprehensive scores for each site were calculated by adding the individual scores of microbial carbon, microbial nitrogen, respiration potential, net nitrogen mineralization, metabolic potential of soil bacteria and earthworm abundance. The comprehensive scores ranged between 0 and 6 .

Radar plots present each biological indicator on one of six axes. The median, first and third quartiles as well as the minimum and maximum individual scores are presented for each LSU. Radar plots were drawn using the function radar chart from the fsmb package in $\mathrm{R}$ 3.2.2.

Differences between regions were tested with a Welch's t.test. Relations between biological indicators were tested with Spearman's correlation analysis. A power analysis of Welch's t-test with a power of 0.8 and alpha of 0.05 was used to determine the number of samples needed to detect significant differences between regions. Data was analyzed with Microsoft Excel 2013 and R 3.2.2.

\section{RESULTS}

Organic carbon content was between 7.9 and $49.4 \mathrm{~g} \mathrm{C} \cdot \mathrm{kg}^{-1}$ with an average of $21 \mathrm{~g} \mathrm{C} \cdot \mathrm{kg}^{-1}$. Total nitrogen content ranged from 0.9 to $5.5 \mathrm{~g} \mathrm{~N} \cdot \mathrm{kg}^{-1}$ with an average of $2.2 \mathrm{~g} \mathrm{~N} \cdot \mathrm{kg}^{-1}$. The $\mathrm{pH}_{\mathrm{H}_{2} \mathrm{O}}$ values varied between 4.03 and 8.31 with an average of 6.6 (Table 1).

Table 1. Minimum, maximum, mean and median values under grasslands in the Ardennes and croplands in the Loam Region - Valeurs minimales, maximales, moyennes et médianes pour prairies en Ardenne et cultures en Région Limoneuse.

\begin{tabular}{|c|c|c|c|c|c|c|c|c|c|}
\hline \multirow[t]{2}{*}{ Biological indicator } & \multicolumn{4}{|c|}{ Grasslands } & \multicolumn{4}{|c|}{ Croplands } & \multirow[t]{2}{*}{$p$} \\
\hline & Min & Mean & Med. & Max & Min & Mean & Med. & Max & \\
\hline Organic carbon $\left(\mathrm{g} \cdot \mathrm{kg}^{-1}\right)$ & 17.1 & 38.4 & 40.4 & 49.4 & 7.9 & 12.2 & 11.5 & 19.8 & $<0.001$ \\
\hline Total nitrogen $\left(\mathrm{g} \cdot \mathrm{kg}^{-1}\right)$ & 2.3 & 4.2 & 4.4 & 5.5 & 0.9 & 1.2 & 1.2 & 2.1 & $<0.001$ \\
\hline $\mathrm{pH}_{\mathrm{H}_{2} \mathrm{O}}$ & 4.03 & 5.47 & 4.81 & 6.53 & 6.36 & 7.31 & 7.43 & 8.31 & $<0.001$ \\
\hline Earthworms $\left(\right.$ Ind $\left.\cdot \mathrm{m}^{-2}\right)$ & 78 & 174 & 183 & 272 & 0 & 54 & 33 & 217 & $<0.001$ \\
\hline Nitrogen mineralization $\left(\mathrm{mg} \cdot \mathrm{kg}^{-1} \cdot \mathrm{d}^{-1}\right)$ & 0.052 & 3.60 & 3.08 & 13.85 & 0.23 & 0.49 & 0.40 & 1.01 & $<0.001$ \\
\hline Microbial carbon $\left(\mathrm{mg} \cdot \mathrm{kg}^{-1}\right)$ & 356 & 1,225 & 1,156 & 2,185 & 127 & 244 & 224 & 419 & $<0.001$ \\
\hline Microbial nitrogen $\left(\mathrm{mg} \cdot \mathrm{kg}^{-1}\right)$ & 113 & 278 & 259 & 551 & 15 & 45 & 43 & 71 & $<0.001$ \\
\hline Metabolic potential of soil bacteria (\%) & 25 & 51 & 52 & 68 & 5 & 39 & 42 & 55 & $<0.01$ \\
\hline Respiration potential $\left(\mathrm{mg} \cdot \mathrm{kg}^{-1} \cdot \mathrm{h}^{-1}\right)$ & 0.61 & 1.31 & 1.08 & 2.30 & 0.13 & 0.65 & 0.56 & 1.59 & $<0.001$ \\
\hline Microbial quotient & 1.25 & 3.43 & 2.87 & 11.9 & 1.25 & 2.01 & 1.87 & 4.66 & 0.02 \\
\hline Metabolic quotient $\left(\mathrm{mg} \cdot \mathrm{kg}^{-1} \cdot \mathrm{h}^{-1}\right)$ & 0.49 & 1.20 & 0.95 & 2.77 & 0.45 & 2.81 & 2.27 & 8.02 & $<0.001$ \\
\hline
\end{tabular}

Differences between LSU were tested with a Welch's t-test - Les différences entre unités paysagères ont été testées par un t-test de Welch. 


\subsection{Biological indicators}

Earthworm abundances varied between 0 and 272 individuals per $\mathrm{m}^{2}$, with an average of 86 individuals per $\mathrm{m}^{2}$. This corresponded to earthworm masses between 0 and $240 \mathrm{~g} \cdot \mathrm{m}^{-2}$ with an average of $69 \mathrm{~g} \cdot \mathrm{m}^{-2}$. Earthworm abundances and masses were correlated $\left(r_{S}=0.81, p<0.001\right)$. Values for microbial biomass ranged between 127 and $2,185 \mathrm{mg} \mathrm{C} \cdot \mathrm{kg}^{-1}$ with an average of $546 \mathrm{mg} \mathrm{C} \cdot \mathrm{kg}^{-1}$ for microbial carbon and between 15 and $551 \mathrm{mg} \mathrm{N} \cdot \mathrm{kg}$ ${ }^{1}$ with an average of $118 \mathrm{mg} \mathrm{N} \cdot \mathrm{kg}^{-1}$ for microbial nitrogen. $\mathrm{C}_{\text {mic }} / \mathrm{N}_{\text {mic }}$ ratios $(\mathrm{g} / \mathrm{g})$ varied between 3.1 and 8.3 with an average of 5.2. Nitrogen mineralization was between 0.052 and $13.85 \mathrm{mg} \mathrm{N} \cdot \mathrm{kg}^{-1} \cdot \mathrm{d}^{-1}$, with an average of $1.5 \mathrm{mg} \mathrm{N} \cdot \mathrm{kg}^{-1} \cdot \mathrm{d}^{-1}$. Respiration potential ranged between 0.13 and $2.30 \mathrm{mg} \mathrm{C}-\mathrm{CO}_{2} \cdot \mathrm{kg}^{-1} \cdot \mathrm{h}^{-1}$ with an average of $0.86 \mathrm{mg} \mathrm{C}-\mathrm{CO}_{2} \cdot \mathrm{kg}^{-1} \cdot \mathrm{h}^{-1}$. Bacteria used between 5 and $68 \%$ of Ecoplate's the carbon substrates with a median of 52\%. Metabolic quotient ranged from 0.45 to 8.02 with an average of 2.32 $\mathrm{mg} \cdot \mathrm{kg}^{-1} \cdot \mathrm{h}^{-1}$ and microbial quotient was between 1.25 and 11.9 with an average of 2.45. Ranges of values found in literature were wider for all biological indicators than ranges identified in this study (Table 2). In general, the ranges measured in Wallonia were within the range found in literature (Chartin et al., 2015).

All biological indicators differentiated between the two LSU (Table 1). Mean values of net nitrogen mineralization, microbial biomass nitrogen $\left(\mathrm{N}_{\text {mic }}\right)$ and microbial biomass carbon $\left(\mathrm{C}_{\text {mic }}\right)$ were more than five times higher in soils under grasslands in the Ardennes than in soils under croplands in the Loam Region. Earthworm abundance (3 times), respiration potential (2 times) and metabolic potential of soil bacteria (1.3 time) showed smaller differences in mean values between the two sites. In grasslands in the Ardennes, correlations were significant between metabolic potential and microbial carbon and nitrogen $\left(\mathrm{r}_{\mathrm{S}}=0.52, p=0.03\right.$ and $\mathrm{r}_{\mathrm{S}}=0.47, p=0.04$ respectively), earthworm abundance and net nitrogen mineralization $\left(\mathrm{r}_{\mathrm{s}}=0.47, p=0.04\right)$. No statistically significant correlations were found between individual biological indicators within croplands in the Loam Region. Soil $\mathrm{pH}_{\mathrm{H}_{2} 0}$ was positively correlated with respiration potential ${ }^{2}\left(\mathrm{r}_{\mathrm{S}}=0.49, p=0.03\right)$ and microbial nitrogen $\left(\mathrm{r}_{\mathrm{S}}=0.47, p=0.04\right)$ in grasslands in the Ardennes and metabolic potential $\left(\mathrm{r}_{\mathrm{s}}=0.40, p\right.$ $=0.02$ ) in croplands in the Loam Region. Soil organic carbon was positively correlated with microbial carbon $\left(\mathrm{r}_{\mathrm{S}}=0.39, p=0.02\right)$ and metabolic potential $\left(\mathrm{r}_{\mathrm{s}}=0.40, p=0.02\right)$ in croplands in the Loam Region. No other significant correlations between biological indicators and chemical indicators were found.

Variability within LSU depended on LSU and the biological indicator observed. Standard deviations (SD) were generally higher under grasslands in the Ardennes (Table 3) than under croplands in the Loam Region. For net nitrogen mineralization and microbial biomass $\left(\mathrm{C}_{\text {mic }}\right.$ and $\left.\mathrm{N}_{\text {mic }}\right)$, SDs were about one order of magnitude higher under grasslands in the Ardennes than under croplands in the Loam Region (Table 3). Earthworm abundance, metabolic potential of soil bacteria and respiration potential (Table 3) had SDs in the same order of magnitude under grasslands in the Ardennes and croplands in the Loam Region. As SDs and true differences in means differed between biological indicators, so did the number of necessary sample sites to calculate significant differences between agricultural regions with a Welch's t-test. The total number of sample sites needed to discriminate between grasslands in the Ardennes and croplands in the Loam Region ranged from $4\left(\mathrm{C}_{\text {mic }}\right.$ and $\left.\mathrm{N}_{\text {mic }}\right)$ to 30 (net nitrogen mineralization) (Table 3 ).

Table 2. Minimum, maximum, mean and median values as well as number of data points from published data under grasslands and croplands in the temperate zone - Valeurs minimales, maximales, moyennes et médianes et nombres de données d'études publiées pour les prairies et les cultures en zone tempérée.

\begin{tabular}{|c|c|c|c|c|c|c|c|c|c|c|}
\hline \multirow[t]{2}{*}{ Biological indicator } & \multicolumn{5}{|c|}{ Grasslands } & \multicolumn{5}{|c|}{ Croplands } \\
\hline & Min & Mean & Med. & Max & n & Min & Mean & Med. & Max & n \\
\hline Earthworms $\left(\right.$ Ind $\cdot \mathrm{m}^{-2}$ ) & 2 & 152 & 51 & 1,347 & 10 & 0 & 190 & 92 & 1,060 & 192 \\
\hline Net nitrogen mineralization $\left(\mathrm{mg} \cdot \mathrm{kg}^{-1} \cdot \mathrm{d}^{-1}\right)$ & -3.44 & 22.7 & 17.4 & 93.8 & 16 & 1.14 & 9.62 & 9.45 & 34.3 & 22 \\
\hline Microbial carbon $\left(\mathrm{mg} \cdot \mathrm{kg}^{-1}\right)$ & 26 & 505 & 398 & 5,028 & 30 & 14.5 & 460 & 259 & 9,760 & 100 \\
\hline Microbial nitrogen $\left(\mathrm{mg} \cdot \mathrm{kg}^{-1}\right)$ & 5.8 & 76 & 72 & 444 & 16 & 0.01 & 35 & 30 & 123 & 22 \\
\hline Metabolic potential of soil bacteria (\%) & 32 & 61 & 58 & 93 & 34 & 16 & 61 & 71 & 97 & 14 \\
\hline Respiration potential $\left(\mathrm{mg} \cdot \mathrm{kg}^{-1} \cdot \mathrm{h}^{-1}\right)$ & 0.001 & 4.5 & 2.0 & 5.6 & 102 & 0.00003 & 2.3 & 0.6 & 32 & 23 \\
\hline Metabolic quotient $\left(\mathrm{mg} \cdot \mathrm{kg}^{-1} \cdot \mathrm{h}^{-1}\right)$ & 0.24 & 2.63 & 1.18 & 30 & 23 & 0.001 & 2.75 & 2.28 & 7.7 & 102 \\
\hline Microbial quotient & 0.19 & 6.57 & 2.35 & 12.6 & 30 & 0.20 & 2.43 & 1.76 & 8 & 116 \\
\hline
\end{tabular}


Table 3. Total mean, standard deviation (SD), coefficient of variation (CV) and necessary sample size for Welch's t-test (n) to detect a significant difference between grasslands in the Ardennes and croplands in the Loam Region - Moyenne absolue, écart-type, coefficient de variation et nombre d'échantillons nécessaires pour un t-test de Welch pour les prairies en Ardenne et les cultures en Région Limoneuse.

\begin{tabular}{|c|c|c|c|c|c|c|}
\hline \multirow[t]{2}{*}{ Biological indicator } & \multirow[t]{2}{*}{ Mean } & \multicolumn{2}{|c|}{ Grasslands } & \multicolumn{2}{|c|}{ Croplands } & \multirow[t]{2}{*}{$\mathbf{n}$} \\
\hline & & SD & $\mathrm{CV}$ & SD & CV & \\
\hline Earthworms $\left(\right.$ Ind $\left.\cdot \mathrm{m}^{-2}\right)$ & 86 & 66 & 77 & 51 & 59 & 12 \\
\hline Nitrogen mineralization $\left(\mathrm{mg} \cdot \mathrm{kg}^{-1} \cdot \mathrm{d}^{-1}\right)$ & 1.5 & 2.84 & 189 & 0.23 & 15 & 30 \\
\hline Microbial carbon $\left(\mathrm{mg} \cdot \mathrm{kg}^{-1}\right)$ & 546 & 516 & 95 & 71 & 13 & 4 \\
\hline Microbial nitrogen $\left(\mathrm{mg} \cdot \mathrm{kg}^{-1}\right)$ & 118 & 119 & 101 & 13 & 11 & 4 \\
\hline Metabolic potential of soil bacteria (\%) & 52 & 10 & 19 & 16 & 31 & 24 \\
\hline Respiration potential $\left(\mathrm{mg} \cdot \mathrm{kg}^{-1} \cdot \mathrm{h}^{-1}\right)$ & 0.86 & 0.49 & 57 & 0.33 & 38 & 20 \\
\hline Metabolic quotient $\left(\mathrm{mg} \cdot \mathrm{kg}^{-1} \cdot \mathrm{h}^{-1}\right)$ & 2.44 & 0.64 & 26 & 1.70 & 70 & 36 \\
\hline Microbial quotient & 2.32 & 2.33 & 100 & 0.63 & 2 & 88 \\
\hline
\end{tabular}

\subsection{Data synthesis}

The combination of biological indicators to a comprehensive score sums up the results for each site. Grasslands in the Ardennes had comprehensive scores between 2.0 and 5.4 (mean value of 3.2) and croplands in the Loam Region comprehensive scores between 0.5 and 1.7 (mean value of 1.1) (Figure 2). The radar plots (Figure 3) showed the distribution of the individual scores for each biological indicator within the two LSU. Biological soil quality in each LSU is characterized through a specific pattern. The radar plots highlight the higher scores and greater range under grasslands in the Ardennes than under croplands in the Loam Region. "logical sieve" approaches are commonly used to rank potentially measured biological indicators based on relevance, applicability and technical criteria (Ritz et al., 2009). In Scotland, this approach was combined with workshops to ensure stakeholders' participation in the assessment process (Aalders et al., 2009). In Wallonia, pertinent biological indicators were selected through a logical sieve approach taking into account the relevance and applicability of the biological indicators, their use in existing monitoring networks, as well as methodological criteria (Malchair et al., 2010)

Selection of sites can either be based on systematic grids or on a stratification following expert judgement (Morvan et al., 2008). The French network RMQS

\section{DISCUSSION}

This pilot study sets the foundation for the establishment of a monitoring network of biological soil quality in Wallonia. Choices in the establishment of a new monitoring network are guided by a multitude of factors specific to each country including the political will and legislations, available funding, as well as pre-existing knowledge, resources and information on potential study sites and methodologies to measure biological indicators.

Approximately 100 potential biological indicators have been identified in the literature (Bispo et al., 2009). To select suitable indicators, iterative numerical

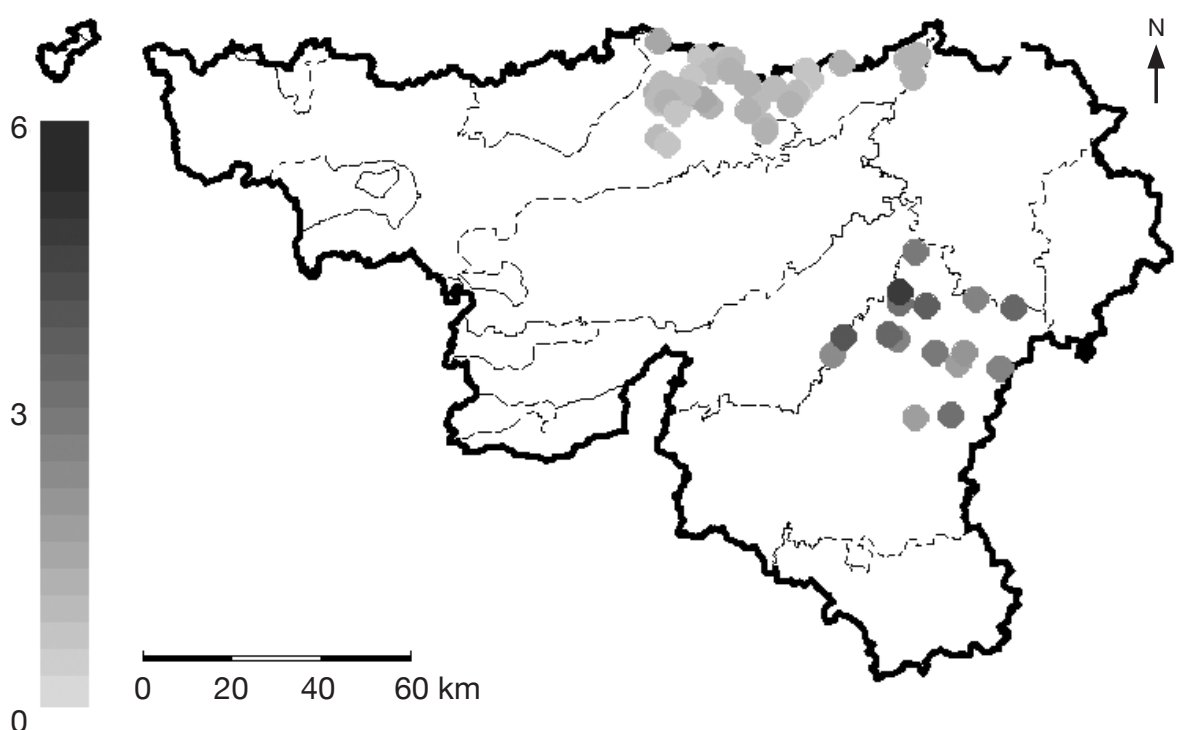

Figure 2. Map of comprehensive scores (0-6) of biological soil quality - Carte des scores compréhensifs (0-6) de la qualité biologique du sol. 

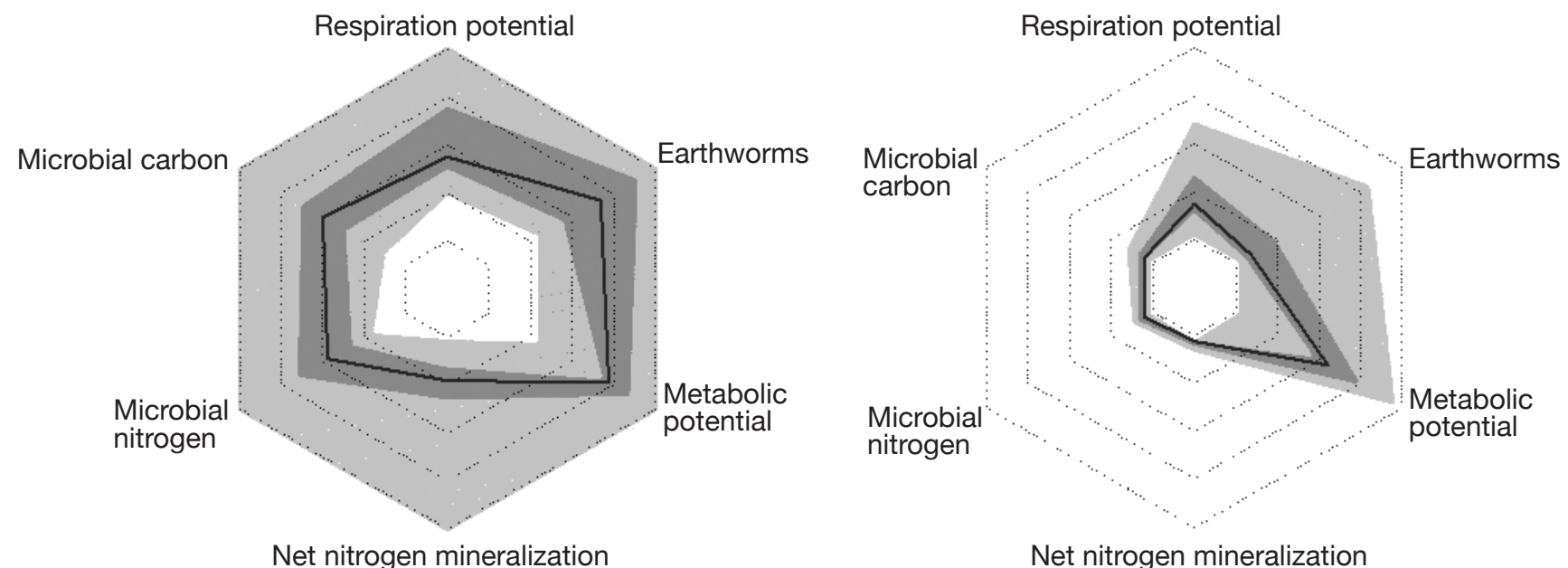

Figure 3. Radar plots for grasslands in the Ardennes (a) and croplands in the Loam Region (b) - Plot radar pour les prairies en Ardennes (a) et les cultures en Région Limoneuse (b).

(Réseau de Mesures de la Qualité des Sols) is an example for the use of a systematic grid $(16 \mathrm{~km} *$ $16 \mathrm{~km}$ ) to select representative sites of the main soil systems and land uses across the whole country (Ranjard et al., 2010). In contrast, the Dutch network NSMN (Netherlands Soil Quality Monitoring Network) uses information available at the farm scale to select sampling sites in different land use and soil type categories (Rutgers et al., 2009). In Wallonia, measurements of biological indicators are introduced in selected sites of the SMN CARBOSOL dedicated to SOC contents and stocks evaluation (Goidts et al., 2009a). This network consists of 592 sites and uses a stratification based on land use, soil type, climate and agricultural region defining hence the Landscape Units, i.e. LSU (CARBOSOL network) (Goidts \& van Wesemael, 2007). CARBOSOL is a dense network of georeferenced soil profiles whose SOC contents were first measured between 1950 and 1970 (De Leenheer et al., 1968) and re-sampled between 2005 and 2014 (Goidts \& van Wesemael, 2007; Chartin et al., 2015). The stratification does not take into account current management (e.g. crops, conservation or conventional agriculture, organic inputs, etc.), though management is thought to explain the variability in carbon stocks and impacts biological indicators.

Baseline values are necessary for the interpretation of data (Nielsen \& Winding, 2002) as they provide a background against which measurements can be evaluated. Baseline values can be defined through descriptive statistics: the minimum and maximum values or, as for example in France, the $1^{\text {st }}$ and $3^{\text {rd }}$ quartiles are used as lower and upper baselines (Cluzeau et al., 2012). In The Netherlands, multidimensional ellipsoids are calculated from a minimum data set of soil parameters to describe the normal operating range (NOR) taking seasonal variability into account (Pereira e Silva et al., 2013; Semenov et al., 2014). In this pilot study, ranges of values that might be used as baselines against which future measurements can be compared were defined for six biological indicators and two ecophysiological quotients in two LSU in Wallonia.

Ranges of values found in the literature are large. Methodological differences between laboratories are likely to account for some of this variability. The selected biological indicators are all measured with widely used techniques (Malchair et al., 2010) and, with the exception of metabolic potential of soil bacteria, ISO norms are available. However the ISO norms are often vague concerning the definition of measurement parameters such as pre-treatment of soil, incubation time and temperature (see ISO 14238:1997 for nitrogen mineralization), resulting in a huge diversity of experimental conditions published in the literature (Creamer et al., 2014). Samples are collected in different seasons, under different weather conditions, causing further variability of up to two orders of magnitude depending on the geographic location of the site and the indicator observed (Wardle, 1998; Gil-Sotres et al., 2005). This often hinders meaningful comparisons between studies performed in different laboratories across European monitoring networks. Furthermore, the range of baseline values is greatly affected by the spatial scale at which they are 
measured. The literature search in this study covered different countries, soil types, management practices and climatic conditions in the temperate zone. Therefore, ranges are much wider than those defined for the two studied LSU in Wallonia. For example, ranges for basal respiration from literature covered six orders of magnitude, while our measurements of respiration potential, an analogous measurement with a shorter pre-incubation and incubation time that might include some flush of microbial activity after sample preparation, defined ranges within two orders of magnitude and a coefficient of variation of $60 \%$ across the two LSU. This emphasizes the need to define baseline values at a meaningful spatial scale, in accordance with the objective of the network. The definition of different baseline values for each LSU in Wallonia, rather than one baseline value for all agricultural sites, is thus a promising approach for establishing a monitoring network. The usefulness of a stratified approach for biological soil monitoring has been shown in other countries, like The Netherlands (Rutgers et al., 2009). All biological indicators enable discrimination between the soil underneath grasslands in the Ardennes and croplands in the Loam Region. Power to discriminate is a mandatory trait of any biological indicator that is to be used to identify meaningful changes to the ecosystem (Cluzeau et al., 2012; Stone et al., 2016b). The significant differences further underline the need to define different baseline values for different LSU. The data set does not enable to quantify how much each divergence between the selected LSU (grassland vs cropland, temperature and precipitation gradient, geology, and historical land use) contributes to the measured differences.

Despite relatively homogenous conditions within agricultural units, spatial variability in each studied LSU resulted in coefficients of variation of up to $189 \%$. Variability in soils under grassland in the Ardennes was higher than variability in soils under cropland in the Loam Region. This is partially due to the higher geomorphological variability in the Ardennes in comparison to the flatter Loam Region, resulting in differences in altitude, exposure and vegetation. Additionally, cropland soils generally have lower variability than grasslands due to tilling (Gubler et al., 2015). Variability was highest for net nitrogen mineralization. Net nitrogen mineralization is a measure integrating nitrogen producing and consuming soil processes which are controlled by different mechanisms (Wang et al., 2001). It has been found to be more variable than microbial biomass and basal respiration and has been reported to be a better discriminator to separate soils by their suitability for different agricultural uses (Benintende et al., 2015). The power of a data set to discriminate between two subsets, in this case two agricultural regions with contrasting characteristics depends on the number of observations, the true difference in means and the standard deviation (Welch, 1947). The number of samples necessary to describe a region is valuable information when setting up a SMN. In this study, a single sampling campaign was performed in autumn, but ideally, seasonal variability of indicators should be considered. For example, the soil fauna and microbial community are sensitive to weather conditions, like soil moisture and temperature (Edwards \& Bohlen, 1996; Waldrop \& Firestone, 2006), causing significant seasonal variability in biological indicators (GilSotres et al., 2005). In temperate climate, spring and autumn are generally considered the best seasons for sampling for biological indicators (Bloem et al., 2005). Furthermore, analyses need to be performed rapidly after soil sampling, as storage can affect microbial activity and functions (Zelles et al., 1991); the number of sites that can be sampled in a single batch is thus limited. We found that with the equipment and resources available, one experienced person can effectively analyze about 40 samples in parallel. About two weeks are required for soil sampling and a further three weeks for laboratory analysis. Two field campaigns are feasible per season (late April to June or September to early November). The time constraints need to be taken into consideration when deciding whether research goals for a SMN can be met.

Scores and radar plots are two frequently used methods to synthesize the data. They present complementary tools that help to answer specific questions. Comprehensive scores were used to create a map, providing a quick overview of the biological soil quality at each site (Figure 2). Calculation of comprehensive scores enhances the power of discrimination between the two LSU. All sites can unambiguously be attributed to either of the two agricultural regions. Sites from croplands in the Loam Region had a comprehensive score from 0 to 1.8 and comprehensive scores for grasslands in the Ardennes ranged from 1.8 to 6 . Indicator scoring is an established method to facilitate assessment of soil quality by providing a summary of values of different measurements and their combination into a single comprehensive score (Wienhold et al., 2009). However the calculation of a comprehensive score results in a loss of information on individual scores, which can be above or below baseline values. Radar plots visualize the distribution of values within the LSU for all biological indicators that can be assessed in a glance. The radar plots show the generally higher values for all biological indicators under grasslands in the Ardennes compared to croplands in the Loam Region, as well as the higher variability between sites under grasslands in the Ardennes than under croplands in the Loam Region. Both tools might be adapted to 
specific questions, by including or excluding different biological indicators or attributing a different weight to individual biological indicators. In combination, both tools are useful for communicating results to stakeholders through the creation of maps and easily understandable graphics of soil quality.

\section{CONCLUSIONS}

This pilot-study sets the foundation for the establishment of a monitoring network of biological soil quality in Wallonia. This first dataset for six biological indicators, respiration potential, microbial biomass $\left(\mathrm{C}_{\text {mic }}\right.$ and $\left.\mathrm{N}_{\mathrm{mic}}\right)$, net nitrogen mineralization, metabolic potential of soil bacteria and earthworm abundance, demonstrates their power of discrimination between two main LSU. Wider ranges were found for grasslands in the Ardennes than for croplands in the Loam Region. This study highlights the need for establishing baseline values of biological indicators of soil quality at meaningful spatial scales, i.e. LSU for Wallonia. Comprehensive scores and radar plots are useful as tools for synthesizing the data. Comprehensive scores transform the biological quality into one number that enables a quick assessment of the soil quality at site level and might be used for the creation of maps of soil quality. Radar plots give more detailed information on the distribution and range of individual biological indicators at the scale of LSU. In combination, they enable a fast assessment of biological soil quality at the regional scale.

\section{Acknowledgements}

This work was funded by the Service public de WallonieDGARNE. The authors would like to thank B. Bosman, M. Bravin, A. Degueldre, A. Piret and M.-C. Requier for technical support and advice.

\author{
Abbreviations \\ CFU: colony forming unit \\ $\mathrm{C}_{\text {mic }}$ : microbial biomass carbon \\ EU: European union \\ LSU: landscape unit \\ $\mathrm{N}_{\text {mic }}$ : microbial biomass nitrogen \\ NOR: normal operating range \\ NSMN: Netherlands Soil Quality Monitoring Network \\ $\mathrm{qCO}_{2}$ : metabolic quotient \\ qmic: microbial quotient \\ RMQS: Réseau de Mesures de la Qualité des Sols \\ SD: standard deviation \\ SMN: soil monitoring network \\ SOC: soil organic carbon
}

\section{Bibliography}

Aalders I. et al., 2009. Considerations for Scottish soil monitoring in the European context. Eur. J. Soil Sci., 60(5), 833-843.

Allen S.E., 1989. Chemical analysis of ecological materials. $2^{\text {nd }}$ ed. Oxford, UK: Blackwell Scientific Publications.

Anderson T.-H. \& Domsch K.H., 1990. Application of ecophysiological quotients $\left(\mathrm{qCO}_{2}\right.$ and $\left.\mathrm{qD}\right)$ on microbial biomasses from soils of different cropping histories. Soil Biol. Biochem., 22(2), 251-255.

Andrews S.S., Flora C.B., Mitchell J.P. \& Karlen D.L., 2003. Growers' perceptions and acceptance of soil quality indices. Geoderma, 114(3-4), 187-213.

Arrouays D. et al., 2012. Generic issues on broad-scale soil monitoring schemes: a review. Pedosphere, 22(4), 456469.

Bastida F., Zsolnay A., Hernández T. \& García C., 2008. Past, present and future of soil quality indices: a biological perspective. Geoderma, 147(3-4), 159-171.

Bending G.D. et al., 2004. Microbial and biochemical soil quality indicators and their potential for differentiating areas under contrasting agricultural management regimes. Soil Biol. Biochem., 36(11), 1785-1792.

Benintende S. et al., 2015. Biological variables as soil quality indicators: effect of sampling time and ability to classify soils by their suitability. Ecol. Indic., 52, 147152.

Bispo A. et al., 2009. Indicators for monitoring soil biodiversity. Integr. Environ. Assess. Manage., 5(4), 717.

Bloem J. et al., 2005. Monitoring and evaluating soil quality. In: Bloem J., Hopkins D.W. \& Benedetti A. Microbiological methods for assessing soil quality. Wallingford, UK: Cabi Publishing, 23-49.

Bünemann E.K., Schwenke G.D. \& Van Zwieten L., 2006. Impact of agricultural inputs on soil organisms-a review. Aust. J. Soil Res., 44(4), 379.

Buysse P. et al.,2013. Fifty years of crop residue management have a limited impact on soil heterotrophic respiration. Agric. For. Meteorol., 180, 102-111.

Cavigelli M.A. et al., 2005. Landscape level variation in soil resources and microbial properties in a no-till corn field. Appl. Soil Ecol., 29(2), 99-123.

Chartin C. et al., 2015. Carbone organique, biomasse et activité microbienne des sols: vers un indicateur de la qualité des sols en Wallonie, rapport final de la subvention CARBIOSOL I. Namur, Belgique: SPWDGARNE.

Cluzeau D. et al., 2012. Integration of biodiversity in soil quality monitoring: baselines for microbial and soil fauna parameters for different land-use types. Eur. J. Soil Biol., 49, 63-72.

Creamer R.E. et al., 2014. Measuring basal soil respiration across Europe: do incubation temperature and incubation period matter? Ecol. Indic., 36, 409-418. 
De Leenheer L., Appelmans F. \& Vandamme J., 1968. Cartes perforées et ordinateur comme instruments pour la caractérisation du sol et pédologie régionale. Le système des canes perforées de la section « caractérisation du sol » de la cartographie des sols de Belgique. Pédologie, 18, 208-227.

Dilly O. et al., 2011. Resilience of microbial respiration, respiratory quotient and stable isotope characteristics to soil hydrocarbon addition. Soil Biol. Biochem., 43(9), 1808-1811.

Edwards C.A. \& Bohlen P.J., 1996. Biology and ecology of earthworms. $3^{\text {rd }}$ ed. London, UK: Chapman \& Hall.

Ettema C.H. \& Wardle D.A., 2002. Spatial soil ecology. Trends Ecol. Evol., 17(4), 177-183.

Gardi C. et al., 2009. Soil biodiversity monitoring in Europe: ongoing activities and challenges. Eur. J. Soil Sci., 60(5), 807-819.

Gil-Sotres F., Trasar-Cepeda C., Leirós M.C. \& Seoane S., 2005. Different approaches to evaluating soil quality using biochemical properties. Soil Biol. Biochem., 37(5), 877-887.

Goidts E. \& van Wesemael B., 2007. Regional assessment of soil organic carbon changes under agriculture in Southern Belgium (1955-2005). Geoderma, 141(3-4), 341-354.

Goidts E., Van Wesemael B. \& Van Oost K., 2009a. Driving forces of soil organic carbon evolution at the landscape and regional scale using data from a stratified soil monitoring. Global Change Biol., 15, 2981-3000.

Goidts E., Van Wesemael B. \& Crucifix M., 2009 b. Magnitude and sources of uncertainties in soil organic carbon (SOC) stock assessments at various scales. Eur. J. Soil Sci., 60(5), 723-739.

Gubler A. et al., 2015. Observatoire national des sols NABO 1985 à 2009. État et évolution des polluants inorganiques et des paramètres associés aux sols. État de l'environnement $n^{\circ} 1507$. Berne : Office Fédéral de l'Environnement.

Gunn A., 1992. The use of mustard to estimate earthworm populations. Pedobiologia (Jena), 36(2), 65-67.

Hart S.C., Nason G.E., Myrold D.D. \& Perry D.A., 1994. Dynamics of gross nitrogen transformations in an oldgrowth forest : the carbon connection. Ecology, 75(4), 880-891.

Havlicek E., 2012. Soil biodiversity and bioindication: from complex thinking to simple acting. Eur. J. Soil Biol., 49, 80-84.

Hofman J. et al., 2003. Novel approach to monitoring of the soil biological quality. Environ. Int., 28(8), 771-778.

Jenkinson D.S. \& Powlson D.S., 1976. The effects of biocidal treatments on metabolism in soil $-\mathrm{V}$ : A method for measuring soil biomass. Soil Biol. Biochem., 8(3), 209-213.

Jenkinson D.S., Brookes P.C. \& Powlson D.S., 2004. Measuring soil microbial biomass. Soil Biol. Biochem., 36(1), 5-7.
Joergensen R.G., 1996. The fumigation-extraction method to estimate soil microbial biomass: calibration of the kEC value. Soil Biol. Biochem., 28(1), 25-31.

Karlen D.L.\& Stott D.E., 1994. A framework for evaluating physical and chemical indicators of soil quality. Soil Sci. Soc. Am. J., Spec. Publ., 53-72.

Karlen D.L. et al., 1997. Soil quality: a concept, definition, and framework for evaluation (a guest editorial). Soil Sci.Soc. Am. J., 61(1), 4.

Koch A. et al., 2013. Soil security: solving the global soil crisis. Global Policy, 4(4), 434-441.

Lal R., 2009. Soils and sustainable agriculture: a review. Sustain. Agric., 28, 15-23.

Lawrence A.P. \& Bowers M.A., 2002. A test of the "hot" mustard extraction method of sampling earthworms. Soil Biol. Biochem., 34(4), 549-552.

Liebig M.A., Varvel G. \& Doran J., 2001. A simple performance-based index for assessing multiple agroecosystem functions. Agron. J., 93(2), 313-318.

Malchair S., Halen H., Moutier M. \& Carnol M., 2010. Appréciation des indicateurs biologiques comme outils d'évaluation de la qualité des sols-rapport final de la convention ULg-SPW, http://orbi.ulg.ac.be/ handle/2268/76044, (03/07/17).

Morvan X. et al., 2008. Soil monitoring in Europe: a review of existing systems and requirements for harmonisation. Sci. Total Environ., 391(1), 1-12.

Nielsen M.N. \& Winding A., 2002. Microorganisms as indicators of soil health. NERI Tech. Rep., 388, 1-85.

Pereira e Silva M.C. et al., 2013. Microbe-mediated processes as indicators to establish the normal operating range of soil functioning. Soil Biol. Biochem., 57, 995-1002.

Rahmanipour F. et al., 2014. Assessment of soil quality indices in agricultural lands of Qazvin Province, Iran. Ecol. Indic., 40, 19-26.

Ramade F., 2008. Dictionnaire encyclopédique de l'écologie et des sciences de l'environnement. Malakoff, France : Dunod.

Ranjard L. et al., 2010. Biogeography of soil microbial communities: a review and a description of the ongoing french national initiative. Agron. Sustain. Dev., 30(2), 359-365.

Ritz K. et al., 2009. Selecting biological indicators for monitoring soils: a framework for balancing scientific and technical opinion to assist policy development. Ecol. Indic., 9(6), 1212-1221.

Robertson G.P. et al., 1999. Soil carbon and nitrogen availability. In: Robertson G.P., Coleman D.C., Bledsoe C.S. \& Sollins P., eds. Standard soil methods for long-term ecological research. New York, USA: Oxford University Press, 258-271.

Rutgers M. et al., 2009. Biological measurements in a nationwide soil monitoring network. Eur. J. Soil Sci., 60(5), 820-832.

Rutgers M. et al., 2012. A method to assess ecosystem services developed from soil attributes with stakeholders 
and data of four arable farms. Sci. Total Environ., 415, 39-48.

Saby N.P.A. et al., 2008. Will European soil monitoring networks be able to detect changes in topsoil organic carbon content? Global Change Biol., 14(10), 24322442.

Schrumpf M., Schulze E.D., Kaiser K. \& Schumacher J., 2011. How accurately can soil organic carbon stocks and stock changes be quantified by soil inventories? Biogeosciences, 8(5), 1193-1212.

Semenov A.V. et al., 2014. Quantitative assessment of soil functioning across a representative range of Dutch soils. Ecol. Indic., 39, 88-93.

Smith P., 2004. How long before a change in soil organic carbon can be detected? Global Change Biol., 10(11), 1878-1883.

Smith P. et al., 2008. Greenhouse gas mitigation in agriculture. Philos. Trans. R. Soc. London Ser. B., 363(1492), 789-813.

Stone D. et al., 2016a. A method of establishing a transect for biodiversity and ecosystem function monitoring across Europe. Appl. Soil Ecol., 97, 3-11.

Stone D. et al., 2016b. Selection of biological indicators appropriate for European soil monitoring. Appl. Soil Ecol., 97, 12-22.

Vance E.D., Brookes P.C. \& Jenkinson D.S., 1987. An extraction method for measuring soil microbial biomass C. Soil Biol. Biochem., 19, 703-707. van der Plas F. et al., 2016. Biotic homogenization can decrease landscape-scale forest multifunctionality. PNAS, 113(13), 3557-3562.

Waldrop M.P. \& Firestone M.K., 2006. Response of microbial community composition and function to soil climate change. Microb. Ecol., 52(4), 716-724.

Wardle D., 1998. Controls of temporal variability of the soil microbial biomass: a global-scale synthesis. Soil Biol. Biochem., 30(13), 1627-1637.

Wang W., Chalk P.M., Chen D.\& Smith C.J., 2001. Nitrogen mineralisation, immobilisation and loss, and their role in determining differences in net nitrogen production during waterlogged and aerobic incubation of soils. Soil Biol. Biochem., 33(10), 1305-1315.

Welch B.L., 1947. The generalization of'student's'problem when several different population varlances are involved. Biometrika, 34, 28-35.

Wienhold B.J., Karlen D.L., Andrews S.S. \& Stott D.E., 2009. Protocol for indicator scoring in the soil management assessment framework (SMAF). Renew. Agric. Food Syst., 24(04), 260.

Zelles L. et al., 1991. Microbial activity measured in soils stored under different temperature and humidity conditions. Soil Biol. Biochem., 23(10), 955-962. 